\title{
Operation Mercury, the Invasion of Crete
}

\author{
HEINZ RICHTER
}

\begin{abstract}
This article is a very brief version of a 320 page book based on sources and publications in English, Greek, French and German from all countries which were involved in the Battle for Crete during the Second World War. It analyses and explains the reasons why the defenders lost despite information provided by ULTRA about the plans of the attackers and both far higher numbers and heavy weapons.
\end{abstract}

\section{Introductory Remarks}

In 1972 I published my first book on Greece in World War II covering the period 1936 to 1946. The book contained several chapters dealing with the Greek-Italian war in the winter of 1940 and a lengthy one describing the German attack against Greece in the spring of 1941 (Operation Marita), with only a few paragraphs referring to the invasion of Crete, Operation Mercury (Merkur). The main weight of the book, however, was on the resistance during the occupation. ${ }^{1}$ In the 1990s I returned to the topic because I noticed that, while there were many historical accounts of the attack on Greece, they were presented according to the national standpoint of the various participants. The content of most books was restricted by the respective nationalities of the authors and there was no comprehensive description of the events based on all available material. Thus I decided to write an account including all publications in English, Greek, Italian, French and German. The result was a volume of over 500 pages dealing with the period from August 1940 to June $1941 .^{2}$

While writing this volume I concluded that Operation Mercury deserved a book of its own and my work followed the same pattern. Thus the book is based on primary sources printed in English, Greek and German and on secondary prints from Britain, New Zealand, Australia, USA, Greece, France, Austria and Germany. This book is the first account based on the contributions in the various languages of all former participants. It appeared in $2011 .^{3}$ The present article is a brief adaption of this 400 page volume. Readers originating from the countries involved will encounter well known facts and interpretations from their national point of view but this applies for all sides. Nevertheless, I am sure that each reader will discover some new things. Of course, many observations and statements are rather brief, but this article is a resumé of a big work.

\section{Preliminaries}

When on 28 October 1940 Mussolini attacked Greece, Churchill and Hitler made statements showing that both had understood the strategic importance of Crete. However, the real military value of Crete was of a rather theoretical nature at that time. The German side might have wanted to use Crete to influence developments in the Near East by attacks of its air force (Luftwaffe) in accordance with the ideas developed by the leaders of the navy and air force, but Hitler was fixed on Operation Barbarossa, the invasion of the Soviet Union. Similarly, the British might have used Crete to attack the Romanian oilfields which were most important for the German war effort, if suitable long range bomber planes had been available in the Near East.

With Hitler otherwise occupied, Churchill ordered the first defence measures to be taken for Crete, although he soon forgot to ensure their realization. Therefore, almost nothing was done in Crete during the following six months. When after the fiasco in Greece in April 1941 criticism began in Britain, Churchill looked for an opportunity to inflict a heavy blow on Hitler, so that the defeat in Greece would be forgotten. ${ }^{4}$ When towards the end of April the 
code breakers in Bletchley Park (Ultra), who had broken the Luftwaffe wireless code, informed Churchill that the Germans planned to conquer Crete from the air, he saw his opportunity for retaliation. ${ }^{5}$ Without Churchill's insistence, Crete, like all other Greek islands, would have fallen into German hands without any fighting.

Militarily speaking, the battle for Crete was a senseless enterprise for the British side. If they had succeeded in holding Crete, they would have been obliged to keep a strong garrison there. As Crete was not self-supporting, they would have been compelled to supply the soldiers and the civilian population which undoubtedly would have led to heavy losses of transport ships. In other words, the British would have encountered the same situation as the Germans after their victory in Crete.

\section{Preparations and planning}

Once the decisions for the conquest of Crete were taken, both sides hectically prepared themselves for the clash; improvising was the main planning characteristic. Since there were no fresh troops in the Near East, the British Commander-in-Chief there, General Wavell, was forced to use troops which had just been evacuated from Greece and had lost all their heavy weapons and most means of transport and communication. The few heavy guns available in Crete were of Italian origin, recently captured in North Africa, and the small number of tanks were barely operational. Supplies had to come over the sea from Egypt, and since the evacuation of Greece it had become clear that the ships could unload only during nighttime because in daylight the Luftwaffe controlled the sky above the Aegean. ${ }^{6}$

The problems of the German side were equally grave. Within a few weeks the airborne and parachutist units had to be transferred to Greece without obstructing the deployment of Operation Barbarossa which was already beginning. At the same time the infrastructure necessary for an airborne operation had to be created in Greece. The operations of two totally distinct Luftwaffe corps (the airborne corps and the combat plane corps) and a huge air transport fleet had to be coordinated by the command of Air Fleet 4 (Luftflotte 4), and after the landing the fighting had to be coordinated. This made high demands on the leadership, which could not always be lived up to by the Luftwaffe because there were no previous models for airborne operations on a strategic level. Operation Mercury was a strategic terra nova.

German supplies could be brought to Crete by air and by sea. However, the first only allowed the transport of light weapons and motorcycles. Heavy weapons and means of transport had to be brought by sea, but the Kriegsmarine (Navy) did not have even a single appropriate vessel in the Aegean. Therefore, kaïkis (fishing boats with a weak motor) had to be used and these could sail only during daytime, since at night the Royal Navy ruled the sea.

The operational concept of the defenders was clear and simple: the three airfields and the harbour in Souda Bay would be defended against seaborne and airborne attacks. Looking at General Student's original plan of attack one can only shake one's head. Obviously, Student had not understood that simple military logic would lead the adversary to expect the aerial attack precisely at these sites and that he would take the necessary precautions which would lead to heavy German losses. The proposal of Luftflotte 4 to drop the airborne troops over an unoccupied area was absolutely right. It should have been clear to Student that the adversary would discover the preparations of this great strategic deployment simply by using reconnaissance aircraft. Thus the element of surprise, the most important element of an airborne attack, would be lost. Crete was much too big for Student's often praised 'oil spill tactics' (Ölflecktaktik), according to which as many attacks as possible occur on different places simultaneously and then merge during the fighting. ${ }^{7}$

The short time for the preparation led to deficiencies in the personal equipment of the airborne troops. Their uniforms and their food had been designed for Norway and were totally 
unsuitable for the Cretan heat. The separate dropping of men and equipment proved to be fatal. Parachutists carried on them a pistol, a knife and a few hand grenades. All other equipment was dropped separately in containers and had to be fetched, a deadly undertaking under fire.

\section{Reconnaissance}

German reconnaissance was a total failure. Rarely in military history had an operation begun in such absolute ignorance. Luftflotte 4 and 12th Army were responsible. The chief of the Abwehr (counterintelligence) was not involved at all. ${ }^{8}$ On the British side the most detailed information about German plans was supplied by ULTRA. But it appears that the Allied commander on Crete, Bernard Freyberg, had not been informed of the real identity of ULTRA and the reliability of the information obtained. According to historian Antony Beevor, Freyberg had been told that the information stemmed from an agent. ${ }^{9}$ Consequently, Freyberg did not fully trust the information and relied on his experience of Gallipoli, and this told him that the attack on Crete would be of an amphibious nature, and he deployed his forces accordingly. A big part of these forces was guarding the shores.

\section{Leadership}

The Germans directed the battle from Athens, the Allies from Cairo. In Athens Luftflotte 4 had the overall command of forces deployed by the air force, army and navy. The commanders-in-chief of these three forces were not in Athens and Berlin did not interfere in the actual operation. Hitler's only intervention was his order not to send airborne troops alone but to also add seaborne units. These were transported by kaïkis and they were sunk by the Royal Navy on the night of 21 May. On British side, in contrast, there existed three independent high commands of the army, navy and air force. The three commanders-in-chief had individual contacts to the War Cabinet via their related ministries, which in turn gave orders separately via the three chains of command. Additionally, Churchill constantly interfered in the decision-making process in Cairo. Thus independent actions and decision, made according to the local situation, were rather reduced.

Freyberg had understood that in view of the great distances between the four places of attack and the miserable communication system he could not lead the battle centrally. He had to convey responsibility to the four local brigade commanders who would be obliged to act independently. This functioned well at Irakleion, Rethymnon and Chania/Galatas, but at the decisive point Freyberg conferred the command to two commanders who were unqualified for this task and too old. Brigadier Hargest who was going to defend Maleme was a politician by profession and the New Zealand divisional commander Puttick thought in World War I categories. Freyberg did not understand that the impending battle needed a dynamic defence, not a static one as had been practiced in World War I.

When deploying his forces on the four landing grounds of the airborne attack, Freyberg made no capital mistake except in the case of Maleme. Accordingly, the parachutists did not succeed with their attacks in the other three places, and they had to change over to a hedgehog position (an all around defence) and without outside help they would have been forced to surrender sooner or later. But at Maleme the west bank of the Tavronitis river and the heights west of it were not occupied, thus enabling the German 2nd Battalion and parts of the 4th Battalion to land without any losses, collect their weapons and go over to the attack. Had these areas been occupied there would have been a similar development to the other three places. A dislodging of the adversary from Maleme airfield would have been impossible. Another decisive mistake was not to destroy the runway thoroughly by blasting big holes in it. But the RAF was against this because they hoped they could use it again and insisted that only removable obstacles were put on the runway. Had it been ruined effectively no transport 
planes could have landed. But the decisive mistake which triggered the defeat was the nonoccupation of the heights west of the Tavronitis. The fact that Freyberg did not insist that this dangerous gap be closed may be characterized as a catastrophic failure. Adding to this judgement is that there was a whole Greek regiment available at Castelli which could have been brought there in time. ${ }^{10}$

The attempt of most of the Allied commanders to lead the battle from the rear as they had done in World War I also led to catastrophes because there were not enough wireless sets and the Cretan telephone network broke down with the first bombing attack. The telecommunications equipment of the New Zealand Division had been transported to Egypt. Thus Freyberg had to rely upon the few wireless sets of the battalions. There were battalions which had only one radio set. The defenders of Rethymnon had four telephones and one wireless set. Often commanders, as in World War I, had to rely upon runners. ${ }^{11}$

But the German concept of leadership was equally problematical: Nominally Operation Mercury was commanded by General Löhr of Luftflotte 4 in Athens, but he left the real control to Student. Luftflotte 4 had already packed up its powerful wireless stations and sent them northward to its deployment area for Barbarossa. Therefore communication between Athens and Crete had to be improvised with weaker wireless sets. Thus communication between Athens and the four battle places was problematical. Often the wireless sets of the airborne troops were smashed on landing.

\section{The strength of the forces}

It was clear that at the beginning of the battle the defenders would be stronger not only by numbers but also principally because in modern battles with mechanized weaponry the defender is always stronger than the attacker. Thus the Cretan defenders had a good chance to beat the aggressors. But although this numerical superiority applied for the island as a whole, locally it was only conditionally correct. There were British battalions which did not come into operation during the first critical phase because they were waiting at the coast for the German amphibious invasion. At another spot, Maleme, one battalion had to bear the brunt of the fighting. There were units which were composed of all sorts of troops, some of which had only basic infantry training. Gunners had almost no infantry weapons. Such units were good in static defence but they did not have any experience in mobile warfare.

The often heard contention that the defenders had heavy weapons is only conditionally right. In reality Freyberg's troops had some artillery of Italian origin and a few barely operational tanks. ${ }^{12}$ But as the defenders did not have traction engines, shifting positions was difficult. It was even more risky during the daytime because of the omnipresent planes of the Luftwaffe. The heavy trench mortars of the parachutists were mobile and in an infantry battle they were superior to the Italian guns.

The decisive factor was the Luftwaffe. The RAF could not make a stand against it because there were no modern planes either in Crete or in the Near East. At most, it could interfere but not really influence the battle. At night, the Royal Navy controlled the sea but during the day it was threatened by the Luftwaffe. The German navy had not one warship in the Aegean.

\section{The battle}

The German attack had to be executed in two waves because there were not enough transport planes for a simultaneous attack on all four targets. Such a double operation needed utmost precision. Only if they were executed in an identical way was there a chance of success. Since the command in Athens knew that there were problems with the refueling of the planes and that clouds of dust would be blown into the air whenever planes started or landed, it was grossly negligent to adhere to the two waves. 
When the transport planes of the first wave returned to the airfields in Greece by noon of 20 May, it became apparent that, due to the dust, the schedule for the second wave could not be kept. Although this was reported, nobody was ready to order the postponement of the dispatch of the second wave, possibly to the next day, or to send the second wave just to Maleme, which was demanded by some officers. ${ }^{13}$ Instead the second wave started in a totally uncoordinated manner and with three hours of delay. The first transport planes arrived at Rethymnon and Irakleion when the combat planes had to fly back because they ran out of fuel. The transport squadrons reached their target areas in total disorder and dropped the parachutists piecemeal within a timeframe of more than two hours. As the invaders were not supported by combat planes, the defenders could inflict heavy losses on the parachutists. Nevertheless, the Germans tried to fulfil their combat mission but in general towards the end of the day they had to form hedgehog positions and pass over to defence.

The only spot where the parachutists had a chance to take an airfield was at Maleme. This meant the defenders had to hold this airfield at any cost and annihilate the aggressors. If the defenders succeeded in denying the airfield to the aggressors, the end of Operation Mercury would be at hand. But this did not work out because of bad communications between the defenders of Height 107 (under Colonel Andrew) and respectively Hargest and Freyberg. Andrew had fended off the German attacks on 20 May but his battalion had suffered heavy losses. When the promised reinforcements did not arrive, he evacuated Height 107 and withdrew to a position further east. It can be argued that he was right in doing so because he knew that his battalion would not survive a further attack by combat planes. Later in the night parachutists moved uphill and occupied the dominating Height 107.

The evacuation of Height 107 by Andrew during the night enabled the conquering of the airfield during the following day and the landing of mountain troops (Gebirgsjäger). Even one single heavy machine gun on Height 107 could have seriously impeded the landing of $\mathrm{Ju}$ 52 transport planes on Maleme airfield or made it totally impossible. Strictly speaking, the battle of Crete was lost during the night of 20 May.

On the German side Löhr and Student grasped only in the evening of 20 May that defeat was threatened if the airfield was not occupied. This meant a change in the operational schedule. This change was initiated by Student who sent the few reserves of the parachutists under the command of Colonel Ramcke to Maleme. They cleared their adversaries from the airfield until the afternoon of 21 May so that the planes with the Gebirgsjäger could land. But in the meantime Student had lost his commanding power. ${ }^{14}$ From now on General Ringel of the Gebirgsjäger was in command and he changed the character of the fighting. While the parachutists had attacked frontally from the air by jumping directly into the enemy positions, Ringel practised a tactical attack based on outflanking infantry moves. His maxim was 'sweat saves blood'. His troops circumvented the defence positions of the adversary by advancing over high mountainous tracks which were not occupied because they were considered impassable. Then they attacked from the rear. So once the airfield was under German control the situation was saved.

But even in the evening of 21 May, after the Gebirgsjäger arrived, Freyberg might have turned the tide if he had ordered a counter attack in brigade strength and had insisted on its execution. He could have recaptured Height 107 if the attack had been conducted in time and with strong enough forces. Instead Freyberg allowed himself to be impressed by the pessimistic situation appraisal of Puttick and Hargest and refrained from attacking in great strength. Being still afraid of a German seaborne attack he even left his forces guarding the sea front. Thus defeat was sure. After the occupation of the Maleme airfield German troops and material could be transported to Crete. The character of the fighting changed. The mountain troops fought according to infantry rules, i.e. each attack was prepared by artillery fire. A little later the British withdrawal began which ended in Sfakia with the evacuation. 


\section{Reasons for the success of the aggressor}

It is astounding indeed that an aggressor, inferior in numbers, who had only light weapons at the beginning, was able to overcome a superior opponent despite the fact that the latter knew the plans of the attack and was prepared for it. This can be ascribed to two factors, the first being the total German air supremacy above the island and above the sea. The uninterrupted air attacks demoralized the defenders. The fight with the Royal Navy was won by the Luftwaffe. It was proven that an air force is capable of beating a fleet which has no air cover. Anti-aircraft guns do not suffice, especially if the special ammunition runs low, as it did. A fleet without air cover is almost defenceless at daytime.

The second factor which led to final success was the fundamentally different concept of leadership. The armies of Great Britain and the Commonwealth followed the principle of order and execution. If there was no order coming from above, even higher officers did not move. This system led - in combination with the catastrophic lack of communications - to passivity. In contrast to this, the German army had practised mission-type tactics since the early-nineteenth-century. Accordingly, all soldiers were educated to autonomous thinking and acting. This principle was even mentioned in the so-called 'ten commandments' of the parachutists: 'You must fully understand the sense of an operation, so that you can act on your own in case your leader dies'. As a result, the lower rank officers and NCOs and even the simple parachutists executed their tasks even if the division commander and most of the regimental commanders had been killed. They did not wait for orders from Athens. Indeed, the battle of Crete was conducted by the lower rank officers, the NCOs and the privates of both sides. The battle was lost by the commanders of the New Zealand troops.

\section{The Greek contribution}

So far historiography on the battle of Crete has rather neglected the role of the Greeks. The Greek regular army was represented by freshly drafted recruits who had gone through very little training, were badly equipped and were lacking of ammunition. Nevertheless, they fought splendidly when they were led well. Without their stubborn resistance against the Gebirgsjäger southwest and south of Chania, the evacuation road to Sfakia would have been blocked and evacuation would have been impossible from there.

The Cretan gendarmes who also were combatants proved to be tough fighters, as was seen in many places especially south of Kissavos/Kastelli and near Kandanos where they killed at least 39 German soldiers in a two-day battle. As many of these gendarmes were not Cretans and were part of the Greek Royal Gendarmerie, republican Cretans did not like them and in Cretan historiography their contribution to the battle of Crete was minimized or totally neglected or attributed exclusively to the Cretan irregulars who had joined them in the fight.

During the months preceding the attack the Greek General Staff made an effort to create a Cretan militia of 3,000 men which would wear blue berets and armbands, thus making them combatants according to the international rules of war. In this militia former soldiers who were too old (40-45 years old) for the regular army would serve. They would be under the command of the gendarmerie. By February 1941 four battalions with 1500 men had been established. The British promised to send weapons but until the German attack nothing arrived. Apparently there was little interest in the British Near East command. Probably Wavell was not ready to take responsibility for the way these units would fight. ${ }^{15}$

The British preferred irregular warfare. Since June 1940 (i.e. before Greece was in the war) SOE agents under the lead of the former archaeologist John Pendlebury were organizing the future resistance. In 1929 Arthur Evans, the excavator of Knossos, made Pendlebury curator and from 1936 till the war he led the excavations in the Dikti mountains. Pendlebury spoke Cretan dialect and knew the island well from his hiking tours. In May 1940 Pendlebury 
and many other archaeologists who were serving in the Army were transferred to military intelligence to organize resistance in Greece. In June 1940, five months before Greece was attacked by the Italians, Pendlebury returned to Crete. During the following months he and some other SOE members organized resistance groups. Some of these groups contributed to the fighting during the German invasion. These groups and others who joined in spontaneously did not know the international rules of war and fought in traditional ways. After the battle Germans reported that some Cretans had mutilated the corpses of the dead. ${ }^{16}$

Cretan stories say that Pendlebury was executed by the Germans. In reality he was already suffering a sepsis when he was shot through the chest in a fight with parachutists. A German orderly administered first aid to him (he was wearing a captain's uniform) and brought him to a house. Later a doctor of the parachutists looked at him. During the night he died in his bed. ${ }^{17}$

\section{Conclusions}

The battle of Crete proved that airborne operations made sense. The high losses were the results of ULTRA and the miserable reconnaissance of the German side by which the element of surprise was lost. If the airborne troops won the battle despite these handicaps, this proves the military quality of these troops. On the side of the Allies this was understood and the formation of airborne troops was intensified. Hitler arrived at the wrong conclusions when he held that the time of airborne operations had come to an end. The German airborne operations against the islands of Leros and Kos in autumn of 1943 indicated that operations with precise tactical aims could be successful and made sense. However, the Allied attack on Arnhem in 1944 showed that strategic aims could not be obtained and led to similar losses as in Crete.

If conducting a war according to the rules of the Hague Conventions (1899 and 1907) and of Geneva Conventions (1864 and 1906) is considered an honourable, 'clean' way of fighting, the battle of Crete can be characterized as such. Generally the regular troops of both sides, including the Greek gendarmerie, adhered to the rules. There were a few exceptions on both sides. There are two well known cases, that of Kontomari where a young lieutenant indoctrinated by Nazi ideas took his private revenge by massacring the males of that village, and the 'authorized' (probably by General Ringel) case of Kandanos where the village was burned down and four old people were killed because shortly before at least 39 German soldiers had been killed by gendarmes and irregulars. On the Allied side the Māori soldiers did not always observe the rules of war and the Cretan irregulars, who had not heard of those conventions, fought in their traditional way. ${ }^{18}$ Details are well documented. ${ }^{19}$

\section{After the war}

Besides the Nuremberg trials, there were other similar war crimes trials in the four German occupation zones (American, British, French and Soviet). In May 1945 the British arrested Student and brought him to the notorious interrogation centre in Kensington Palace (London Cage) ${ }^{20} \mathrm{He}$ was put under duress, the interrogators believing that he was 'the typical stubborn conceited Nazi General'. ${ }^{21}$ In 1946 Student was brought to a court at Lüneburg in the British zone of occupation in Germany to be tried under sentence of death for alleged war crimes committed by his troops in Crete. Most of the witnesses for the prosecution were former British soldiers, not New Zealanders who had borne the brunt of the fighting. After listening to the witnesses for the defence the court dropped most of the charges and when General Inglis (a New Zealand Crete veteran) appeared before the court he gave testimony in favour of Student. Therefore Student had to be acquitted. ${ }^{22}$ Additionally, one should not forget that Student had been removed from his command from the 21 May 1941 until the end of the Cretan campaign. From that day on orders were given by the Commander of Luftflotte 4, General Löhr. ${ }^{23}$ After the end of the trial the British were so convinced of Student's innocence 
that they rejected a Greek demand to transfer Student to Athens to stand trial. Student was no war criminal.

The New Zealanders, who had borne the main weight of the fighting, were of the opinion that the battle of Crete had been fought in a tough but fair way. Thus in 1959 the Secretary of the New Zealand Crete Veterans Association wrote a letter to Student in which he suggested that Student become honorary vice-president of the New Zealand organization and that there be mutual honorary membership for the members of the New Zealand and German Crete veteran associations. Student accepted and to this day 90 year old parachutists proudly show their honorary membership diploma of the New Zealand Crete Veterans Association. ${ }^{24}$ 


\footnotetext{
${ }^{1}$ Heinz A. Richter, Griechenland zwischen Revolution und Konterrevolution 1936 - 1946 (Frankfurt: Europ. Verl.-Anst., 1973); Greek edition, Heinz A. Richter, $\Delta v ́ o$ g $\pi \alpha v \alpha \sigma \tau \alpha ́ \sigma g l \varsigma ~ \kappa \alpha l ~ \alpha v \tau \mathrm{g} \pi \alpha v \alpha l \varsigma \sigma \tau \eta v E \lambda \lambda \alpha ́ \delta \alpha 1936-$ 1946, Athens, 1977, 2 vols.
}

${ }^{2}$ Heinz A. Richter, Griechenland im Zweiten Weltkrieg August 1939 - Juni 1941 (Mannheim: Historisches Inst. der Univ., 1997); 2nd revised edition Ruhpolding, 2011; Greek edition: Heinz A. Richter, H $\iota \tau \alpha \lambda o-\gamma \mathrm{g} \rho \mu \alpha \nu \kappa \eta$ $\mathrm{g} \pi \imath \theta \mathrm{g} \sigma \eta^{\prime} \mathrm{g} v \alpha \dot{v} \tau \iota o v ~ \tau \eta \varsigma^{\prime} E \lambda \lambda \alpha ́ \delta o \varsigma$, Athens, 1998.

${ }^{3}$ Heinz A. Richter, Operation Merkur. Die Eroberung Kretas im Mai 1941 (Mainz: Rutzen, 2011). Greek

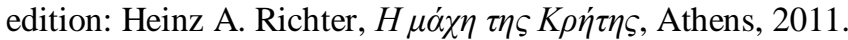

${ }^{4}$ On the Greek-Italian war and on the Operation Marita see Heinz A. Richter, Griechenland im Zweiten

Weltkrieg, passim.

${ }^{5}$ Cabinet History Series, I, Hist. (B) 3., Nr. 222, 96. 'It seems clear from our information that a heavy air-borne attack by German troopsand bombers will soon be made on Crete ... It ought to be a fine opportunity for killing parachute troops. The island must be stubbornly defended.' See John Keegan, The Second World War (London: Penguin, 1989), 131.

${ }^{6}$ See Freyberg's letter to Wavell in Winston Churchill, The Second World War, Vol. 3 (London: Cassell, 1950), 243.

${ }^{7}$ Drops of oil tend to spread and grow in size in all directions.

${ }^{8}$ Ehrengard Schramm von Thadden, Griechenland und die Großmächte im Zweiten Weltkrieg (Wiesbaden:

Steiner, 1955), 221.

${ }^{9}$ Antony Beevor, Crete: The Battle and the Resistance (London: John Murray, 1991), 89.

${ }^{10}$ Ibid., 94; Laurie Barber \& John Tonkin-Covell, Freyberg Churchill's Salamander (London: Random House, 1989), 36.

${ }^{11}$ Albert Palazzo, Battle of Crete (Canberra: Army History Unit, 2007), 19; C. A. Borman, Divisional Signals

(Wellington: War History Branch, 1954), passim.

${ }^{12}$ Gavin Long, Greece, Crete and Syria, (Canberra: Australian War Memorial, 1953), $215 f$.

${ }^{13}$ Rüdiger von Heyking, Commitment of Parachute Troops by the 2nd Air Transport Wing (Special Purpose): Crete 20 May 1941 (Garmisch, 1947); USAREUR Historical Division MS \# B; Hermann Götzel, ed., Generaloberst Kurt Student und seine Fallschirmjäger. Die Erinnerungen des Generaloberst Kurt Student, Friedberg, 1980, 247; Werner Pissin, Die Eroberung der Insel Kreta durch deutsche Fallschirmjäger und Luftlandetruppen im Jahr 1941 (Karlsruhe, 1957), 133; Study of the Historical Division US Air Force in Maxwell Air Force Base, Montgomery Alabama.

${ }^{14}$ Richter, Merkur, $156 f$.

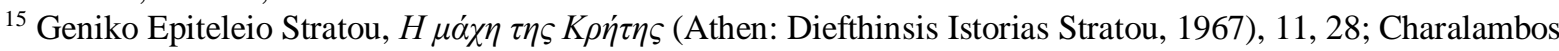

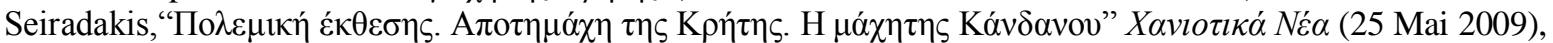
$24 \mathrm{f}$.

${ }^{16}$ Wehrmachtsuntersuchungsstelle für Verletzungen des Völkerrechts, 'Völkerrechtsverletzung der Feindmächte beim deutschen Einsatz auf Kreta' im Juli 1941, BA MA, RW 2/Vol.138, 80ff; Auswärtiges Amt, ed., Völkerrechtsverletzungen der britischen Streitkräfte und der Zivilbevölkerung auf Kreta (Berlin, 1942).The latter contains almost 100 affidavits from German soldiers and Greeks collected right after the end of the fighting. There exist only three copies of the mimeographed report, one is in my possession.

${ }^{17}$ On Pendlebury see Richter, Merkur, 254-263.

${ }^{18}$ On Kontomari see Richter, Merkur, 268f; on Kandanos see Richter, Merkur, $266 \mathrm{f}$.

${ }^{19}$ Wehrmachtsuntersuchungsstelle für Verletzungen des Völkerrechts, 'Völkerrechtsverletzung der Feindmächte beim deutschen Einsatz auf Kreta' im Juli 1941, BA MA, RW 2/Vol.138, 80ff; Auswärtiges Amt, ed., Völkerrechtsverletzungen der britischen Streitkräfte und der Zivilbevölkerung auf Kreta, Berlin, 1942.The latter contains almost 100 affidavits from German soldiers and Greeks collected right after the end of the fighting. There exist only three copies of the mimeographed report, one is in my possession.

${ }^{20}$ A. Scotland, The London Cage (London: Evans Brothers, 1957).

${ }^{21}$ Callum Macdonald, The Lost Battle: Crete 1941 (London: The Free Press 1993), 304.

${ }^{22}$ For details on the trial Richter see Merkur, 287-290.

${ }^{23}$ Richter, Merkur, 136; based on the unpublished Richthofen Diary.

${ }^{24}$ On the reconciliation with the New Zealanders see Ibid., $290 f$. 